\title{
A survey on relationship among consumer personal characteristics, brand personality and brand love
}

\begin{abstract}
Ali Eilaghi Karvandi*
Department of Management and Accounting, Kerman Branch, Islamic Azad University, Kerman, Iran

C H R O N I C L E

Article history:

Received January 5, 2016

Received in revised format June 15,2016

Accepted July 10, 2016

Available online

July 11, 2016

Keywords:

Brand love

Brand personality

Personal characteristics

A B S T R A C T

Consumer's personality traits, as one of the most important aspects of human psychological tendency, may influence people towards different brands. Therefore, the owners of most wellknown brands also try to learn more about people's personal characteristics to gain more market shares. The purpose of this paper is to find out more about consumer personality, which creates motivation in consumer's mind and to learn more about the effect of this image on consumer's interest on purchasing products. The population of this survey includes all people in city of Tehran, Iran who own one of Apple's products. The results of the survey have indicated that neuroticism, extroversion, openness, compatibility, loyalty and brand love, as the main characteristics of brand personality, maintained positive impacts on brand love.
\end{abstract}

C 2016 Growing Science Ltd. All rights reserved.

\section{Introduction}

For several decades, many have tried to understand how to drive favorable brand attitudes, brand loyalty, repeat purchase, customer lifetime value, customer advocacy, and communities of like-minded people organized around brands (Swystun, 2006). Many studies have established with inspiration from attitude theory and, later, socio-cultural theories. The new paradigm concentrated on the relationships that formed between brands and consumers: an idea that had obtained traction in business-to-business marketing scholarship where physical relationships are created between buyers and sellers. A consumer-brand relationship, also known as a brand relationship, is something that consumers, think, feel, and gain with a product or company brand. Brand love is one of most important factors, which may influence on people's personal characteristics. A person who loves a particular brand will more likely to purchase products of that brand. Therefore, it is important to learn about the factors, which create such emotion among consumers. Carroll and Ahuvia (2006) performed a survey on antecedents and outcomes of brand love and reported that satisfied consumers' love was bigger for brands in product categories perceived as more hedonic and for brands that provide more benefits. Brand love, in the * Corresponding author.

E-mail address: ali.kervandi@gmail.com (A. Eilaghi Karvandi) 
survey, was linked to higher levels of brand loyalty and positive word-of-mouth. They also reported that satisfied consumers were less loyal to brands in more hedonic product categories and to involve in more positive word-of-mouth about self-expressive brands. According to Albert et al. (2008), consumers could develop feelings of love toward some brands, but the meaning and underlying dimensions of this construct may need more development. Batra et al. (2012) studied the nature and consequences of brand love and discussed that research on brand love requires to be constructed to find out how consumers actually experience this phenomenon. They performed two qualitative investigations to find different elements of the consumer prototype of brand love. They explored how these elements could be modeled as both first-order and higher-order structural models and reported seven core elements including self-brand integration, passion-driven behaviors, positive emotional connection, long-term relationship, positive overall attitude valence, attitude certainty and confidence (strength), and anticipated separation distress. The prototype also included quality beliefs as an antecedent of brand love and brand loyalty, word of mouth, and resistance to negative information as outcomes. Albert and Merunka (2013) investigated a model of brand love, which includes both its antecedents and its consequences. The model was originated in a causal method and features built consumer-brand relationship constructs. They reported strong relationships between the two antecedents; namely trust and identification, and brand love, and between brand love and its consequences.

\section{The proposed study}

This paper presents an empirical investigation to study the effects of different brand personality including neuroticism, extroversion, openness, compatibility, loyalty on brand love for products of Apple in city of Tehran, Iran. The study designs three questionnaires, one for brand personality, personality traits (Aaker, 1997) and the other for brand love in Likert scale. Cronbach alphas for brand personality, personality traits and brand love are $0.84,0.75$ and 0.86 , respectively. Since the population of this survey was unlimited, the study uses the following to calculate the sample size,

$$
N=Z_{\alpha / 2}^{2} \frac{p \times q}{e^{2}},
$$

where $N$ is the sample size, $p=1-q$ represents the probability, $z_{\alpha / 2}$ is CDF of normal distribution and finally $\varepsilon$ is the error term. For our study, we assume $p=0.5, z_{\alpha / 2}=1.96$ and $e=0.05$, the number of sample size is calculated as $N=385$. The study has distributed 400 questionnsires to maintain the minimum desirability of the survey.

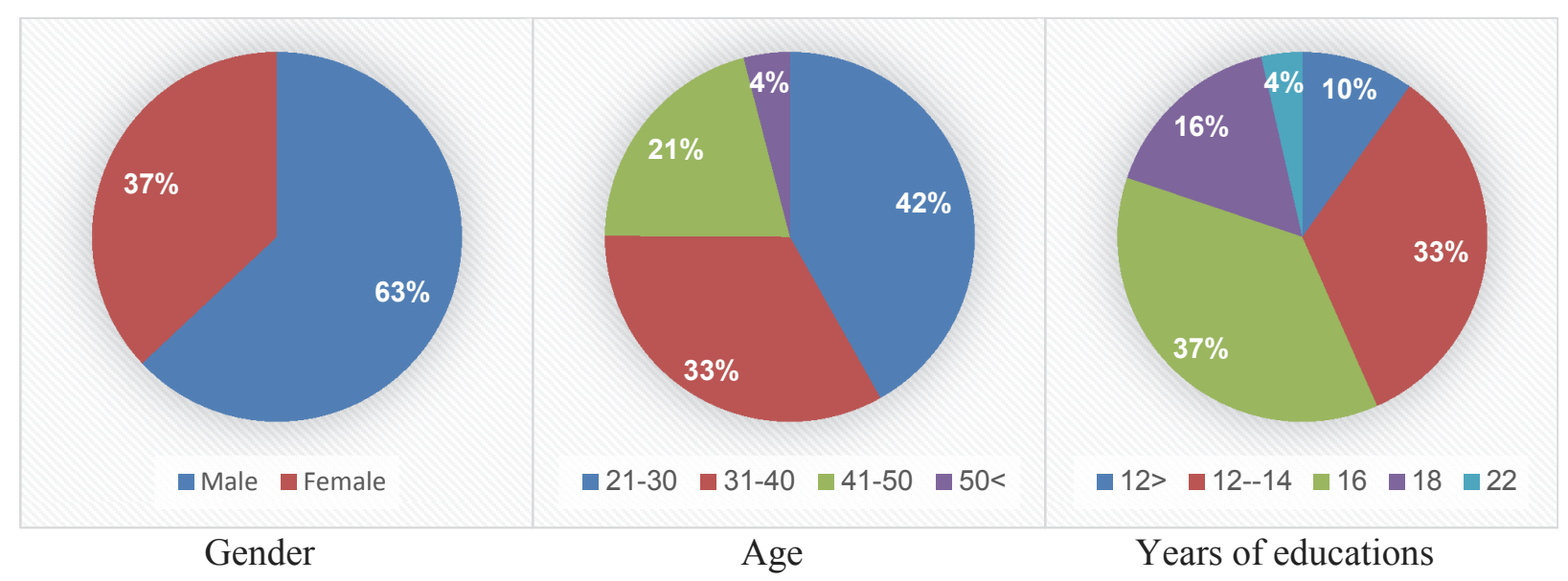

Fig. 1. Personal characteristics of the participants 
As we can see from the results of Fig. 1, 63\% of the people who took part in this survey were male and the remaining $37 \%$ were female. In terms of their age, $75 \%$ of them aged less than 40 and the rest of them were mainly middle aged people and finally, most participants in our study hold good educational background. Fig. 2 demonstrates the structure of the proposed study,

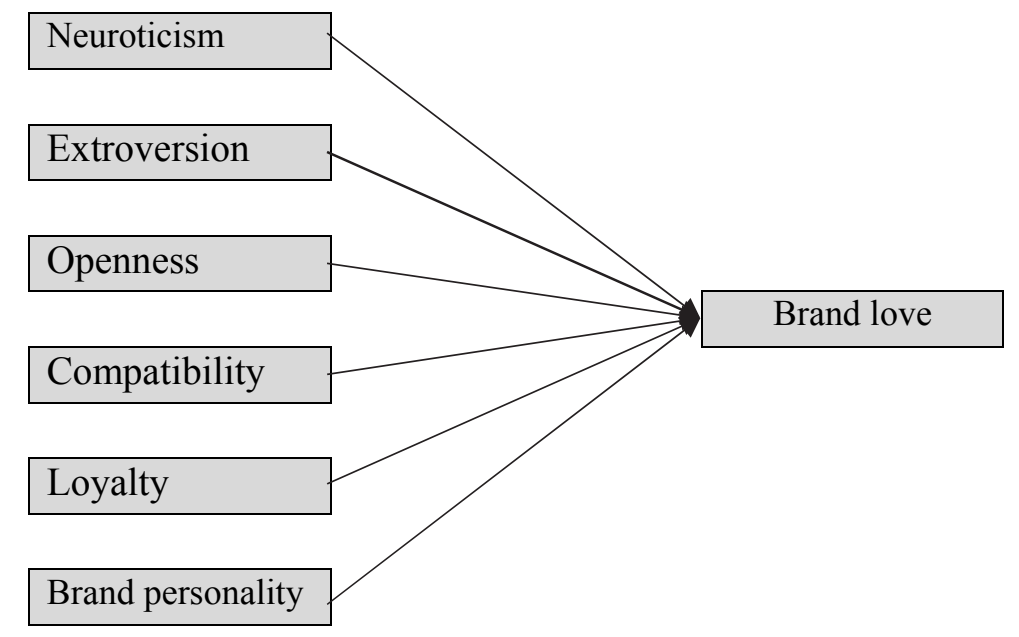

Fig. 2. The structure of different brand personality factors on brand love

As we can observe from Fig. 2 there are six hypotheses associated with the proposed study of this paper. The implementation of Kolmogorov-Smirnov test has indicated that the data were not normally distributed and thus, we use Spearman correlation test to verify the hypotheses of the survey.

\section{The results}

In this section, we present the results of the implementation of Spearman correlation as well as Stepwise regression techniques. Table 1 shows the results of our survey.

\section{Table 1}

The summary of Spearman correlation test

\begin{tabular}{lccc}
\hline Hypothesis & Correlation & Sig. & Result \\
\hline Neuroticism $\rightarrow$ brand love & 0.280 & $0.004^{* *}$ & Confirmed \\
Extroversion $\rightarrow$ brand love & 0.428 & $0.000^{* *}$ & Confirmed \\
Openness $\rightarrow$ brand love & 0.358 & $0.002^{* *}$ & Confirmed \\
Compatibility $\rightarrow$ brand love & 0.281 & $0.0019^{* *}$ & Confirmed \\
Loyalty $\rightarrow$ brand love & 0.428 & $0.009^{* *}$ & Confirmed \\
Brand personality $\rightarrow$ brand love & 0.336 & $0.000^{* *}$ & Confirmed \\
\hline
\end{tabular}

*Sig. $<0.05$

$* *$ Sig. $<0.01$

Based on the results of Table 1, all hypotheses of the survey have been confirmed and there were positive and meaningful relationships between five brand personality and brand love. The results have also indicated that being extroversion as well as loyalty play the most important roles followed by being openness and neuroticism. Table 2 shows the results of Stepwise regression model,

Table 2

The summary of Stepwise regression

\begin{tabular}{|c|c|c|c|c|c|}
\hline Variable & $\begin{array}{c}\text { Change } \\
\text { coefficient }\end{array}$ & Standard error & $\begin{array}{c}\text { Standard } \\
\text { coefficient }\end{array}$ & t-value & Sig. \\
\hline Intercept & 57.401 & 4.586 & & 12.904 & .000 \\
\hline Openness & .581 & .244 & .426 & 2.973 & .000 \\
\hline Loyalty & .523 & .215 & .363 & 2.426 & .002 \\
\hline Brand personality & .471 & .163 & .329 & 2.111 & .010 \\
\hline
\end{tabular}


As we can see from the results of Table 2, openness has maintained the highest positive effect on brand love followed by loyalty and bran personality.

\section{Conclusion}

During the past few years, there have been strong competition among mobile providers in Iran. Two major mobile providers; namely Apple and Samsung have had strong competition making it difficult for other brands to gain more market share. One of the primary concerns on market development in mobile industry is to find out more about consumer's personal characteristics. In this survey, we have performed an empirical investigation to determine different personality characteristics on brand love in mobile industry. The study was performed among Iranian people who lived in capital city of the country and we believe the market was more attractive for major brand owners. The results of our survey have concluded that being openness influenced the most on brand love followed by brand loyalty. The results of this survey are consistent with other finding reported in the literature (Sarkar et al., 2012; Rauschnabel \& Ahuvia, 2014). Rageh Ismail and Spinelli (2012), for instance, reported that only brand image was a determinant of brand love, which could also influence word of mouth along with brand personality. Roy et al. (2013) presented a series of research propositions to explicate the interrelationships between antecedents of brand love and its consequences on the other and reported similar results with our findings. We hope this survey shed light on the relative importance of brand love and more studies will be accomplished in future to explore other characteristics of this brand love.

\section{Acknowledgement}

The authors would like to thank the anonymous referees for constructive comments on earlier version of this paper.

\section{References}

Aaker, J. L. (1997). Dimensions of brand personality. Journal of Marketing Research, 34(3), 347-356. Albert, N., Merunka, D., \& Valette-Florence, P. (2008). When consumers love their brands: Exploring the concept and its dimensions. Journal of Business research, 61(10), 1062-1075.

Albert, N., \& Merunka, D. (2013). The role of brand love in consumer-brand relationships. Journal of Consumer Marketing, 30(3), 258-266.

Batra, R., Ahuvia, A., \& Bagozzi, R. P. (2012). Brand love. Journal of Marketing, 76(2), 1-16.

Carroll, B. A., \& Ahuvia, A. C. (2006). Some antecedents and outcomes of brand love. Marketing letters, 17(2), 79-89.

Rageh Ismail, A., \& Spinelli, G. (2012). Effects of brand love, personality and image on word of mouth: The case of fashion brands among young consumers. Journal of Fashion Marketing and Management: An International Journal, 16(4), 386-398.

Rauschnabel, P. A., \& Ahuvia, A. C. (2014). You're so lovable: Anthropomorphism and brand love. Journal of Brand Management, 21(5), 372-395.

Roy, S. K., Eshghi, A., \& Sarkar, A. (2013). Antecedents and consequences of brand love. Journal of Brand Management, 20(4), 325-332.

Sarkar, A., Ponnam, A., \& Murthy, B. K. (2012). Understanding and measuring romantic brand love. Journal of Customer Behaviour, 11(4), 324-347.

Swystun, J. (Ed.). (2006). The brand glossary. Palgrave Macmillan.

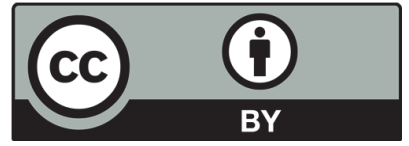

(C) 2016 by the authors; licensee Growing Science, Canada. This is an open access article distributed under the terms and conditions of the Creative Commons Attribution (CC-BY) license (http://creativecommons.org/licenses/by/4.0/). 